\title{
Instructional Leadership In Elementary School SD Muhammadiyah Boyolali
}

\author{
Sabar Narimo ${ }^{1}$ Sutama $^{2}$, Meggy Novitasari ${ }^{3}$ \\ \{Sabar.Narimo@ums.ac.id, sut197@ums.ac.id, meggy151013@gmail.com\}
}

Universitas Muhammadiyah Surakarta, Surakarta, Indonesia

\begin{abstract}
The purpose of this research was to describe the instructional leadership employed by principals in improving the students' learning outcomes. This research was a qualitative research. The data collection techniques were interview, observation, and documentation. The data analysis technique was interactive method. The result of the study indicates that the principals were the most instrumental element in improving the quality of education. To improve the quality of education, the school principal conducted an instructional leadership, namely through the formulation of the school's vision and mission, the management of meaningful learning, and the maintenance of a positive school climate. These three dimensions were then broken down to eleven descriptors.
\end{abstract}

Keywords: leadership, instructional, elementary school

\section{Introduction}

Education is a fundamental part of a national development process that determines a country's economic growth. Education is also an investment in human resource development; the importance of the sustainable improvement and development human resources is one of the policies to improve the quality of education. One of the salient issues in organizing education in Indonesia is finding the ways to improve the quality of education in the midst of the rapid changing times. Based on Programme for International Study Assessment (PISA) in 2015, Indonesia ranked among the lowest ranked countries in the education quality achievement. Of the 72 countries that were assessed, Indonesia's mathematical ability ranked $65^{\text {th }}$; that of science ranked $63^{\text {rd }}$; and that of reading ranked $66^{\text {th }}$. This was indicated by the ranking earned in the ability to read, mathematics, and science of the 15 year old students.

Among the components that are crucial in the process of learning in schools is the teacher. On the grounds of the importance of the roles and responsibilities of teachers, Law No. 14/2005 concerning Teachers and Lecturers declares teachers as the learning agents that must become the facilitators, motivators, promoters, learning manipulators, and learning inspirations for the students. In addition, they also have the main tasks of educating, teaching, guiding, directing, training, assessing, and evaluating the students in the early childhood education through the formal education, basic education, and secondary education. Thus teachers have an important and strategic position and role to shape the nation's personality through the development of the learner's potential and the desired values. One of their tasks in schools is to provide services to the students so that they become the students who are in harmony with the goals of the school. 
In fact, the reality has not yet matched the expectation. Based on the research undergone by the Research and Development Agency of the National Education Department in 2006, the low quality of our education was caused by numerous factors; one of them that contributed greatly was teacher factor. Research conducted by UNESCO through the 2016 General Education Monitoring (GEM) Report positioned the education in Indonesia in the $10^{\text {th }}$ place out of 14 developing countries. Furthermore, in the assessment of the teacher's quality, Indonesia ranked $14^{\text {th }}$ out of the 14 developing countries which means it was in the lowest position.

This is the challenge for Indonesians to improve the quality of teachers in schools. This also means that the four teacher competencies, including professional, pedagogical, personal, and social competencies, must be improved. The two absolute competencies for the personal development that need to be improved are professional competency and pedagogical competency. Professional competency is needed to improve the ability of the teachers in understanding the learning content; while pedagogical competence is needed to improve their ability in teaching, making plans, assessing, designing the learning methods, managing the classroom, etc. In order for them to improve their competencies, apart from the teachers themselves, the principals also play a very important role.

Priansa (2014: 49) argues that a principal is defined as the functional personnel of teacher who is given the task of leading the school where the teaching and learning process is held, or the place where the interaction occurs between the teacher giving the lesson and the students taking the lesson. One of the principal's tasks is instructional leadership. Instructional leadership, according to Eggen \& Kauchak (2004), is an action taken (by a principal) to develop a productive and satisfying work environment for the teachers that is ultimately able to create the improve conditions for the student's learning. Meanwhile, according to Bush and Glover (2013), it is a leadership that emphasizes the components that are closely related to learning, including curriculum, teaching and learning process, assessment, teacher development, excellent service in learning, and the development of learning communities in schools.

The main aim of instructional leadership is to provide excellent service to all students so that they are able to develop their potential, talents, interests and needs. In addition, it also functions to facilitate learning so that the students' learning achievement increases, learning satisfaction is higher, learning motivation is higher, curiosity is realized, creativity is fulfilled, innovation is realized, entrepreneurial spirit is formed, and awareness for lifelong learning increases as science, technology, and arts develop rapidly and grow well.

Based on the description, how is the role of the principal as a learning leader in improving the student's learning outcomes in elementary school SD Muhammadiyah Boyolali? This study aimed to describe the instructional leadership of the principal to improve the student's learning outcomes.

\section{Method}

The study belongs to qualitative research of which results are descriptive data in the form of written or oral words from people and the observable behavior. The research was conducted at elementary school SD Muhammadiyah Boyolali, Central Java, from January to July 2019. 
The data collection techniques employed in the study were interviews, observation, and documentation. The data analysis technique used was non-statistic method, namely the qualitative data analysis interactive method, meaning that the obtained data on the instructional leadership performed by the school's principal was reported based on the real situations which were then analyzed descriptively to get a picture of the facts. The steps of the data analysis were: (1) data reduction, (2) data display, and (3) conclusion drawing.

\section{Result and Discussion}

School's principals have a chief role in improving the quality of education in schools. They are required to be able to lead as well as organize and manage the implementation of teaching and learning programs held in the school. It is also a must for them to be able to become the supervisor of the team consisting of the teachers, staff, and students in realizing an effective and efficient teaching and learning process so that the learning productivity is achieved which can ultimately improve the quality of the education.

A principal also has a great responsibility in managing the school management that is directly related to the learning process. This is in accordance with Mulyasa (2013: 24)'s claim that the principal is the most instrumental component in improving the quality of education. In line with this, Ermita (2010) states that the principal is among the components that play a role in the management of educational institutions. The maximum achievement of the educational goals depends on the success in organizing the education and learning at every level of the education unit.

To be able to improve the quality of education, a principal must have a vision, mission, and education management strategy as a whole and be oriented to the quality of education. Principals are expected to create a harmonious working atmosphere and to create a work climate and school culture that can motivate the teachers to increase their work productivity and effectiveness in order to achieve the education goals. To be able to improve the student's learning outcomes, the learning process must become the focus of the principal's attention. The principal's instructional leadership at elementary school SD Muhammadiyah Boyolali as an effort to improve the student's learning outcomes was reviewed based on the learning leadership model conveyed by Hallinger and Murphy.

\section{A. Defining the School's Mission}

In this dimension, there are two descriptors, namely framing the school's goals and communicating the school goals. The vision, mission, and objectives of elementary school SD Muhammadiyah Boyolali were formulated and established by the Foundation. The school's principal and all school's community are the executors. Therefore, the principal must be able to formulate a joint program with the school's community to achieve the school's goals. Once the program is prepared, it is then communicated with all school members and stakeholders. All programs arranged by the school's principal must be oriented towards the improvement of the student's learning outcomes so that the quality of education in schools is improved and the school's goals are achieved. 
These findings are in line with the research on the ability of principals related to administrative competence carried out by Adegbemile entitled Principal's Competency Needs for Effective Schools Administration in Nigeria at the secondary school level in South Geo Barat, Nigeria. The results of the study show that instructional leadership skills needed by principals for the effective school administration include those of: (1) collaborating with the teachers to determine the school's goals; (2) providing the facilities; (3) supervising of the lesson plans; (4) undergoing the teaching and learning activities; and (5) evaluating plans and implementing the curriculum.

Another study carried out by Prytula, Noonan, and Hellsten entitled "Toward Instructional Leadership: Principals' Perceptions of Large Scale Assessment in Schools" examined the principals' perceptions of the reform of the measurements of the principals' performance and how these measurements affected their role as principals. The results show that the reform of the measurements of the principal performance had a positive effect on the instructional leadership which including the framing the school's goals, improving the implementation of the instruction, and changing the measurements of the student's learning.

The findings of the research explain that framing the school's goals is important to be done to set the learning direction and objectives. To determine school's goals, it is prominent to take into account both situation and the conditions that lead to the success of their realization. Target as a benchmark is fundamental to achieve a successful realization of school's goals. Among the ways is to use SMART (Specific, Measurable, Achievable, Realistic, and Time bound) method. It means that the targeted school goals must be specific/focused, measurable, attainable, adjusted to the situation and condition of the school, and must have a deadline for the achievement. Therefore, the school's goals are more feasible to achieve. The chief among them is the maximum learning outcomes that ultimately affect the quality of the education.

\section{B. Managing the Instructional Program}

Three descriptors namely supervising and evaluating the learning, coordinating the curriculum, and monitoring the student's learning progress belong to this dimension. The second dimension of this is the stages of the main process of learning activities. The quality of education is very dependent on the teaching and learning process. Therefore, the principal as a learning leader needs to supervise and evaluate it. The principal of elementary school SD Muhammadiyah Boyolali conducted annual supervision of the learning at the beginning of the school year. This is an attempt made to help and develop the teacher's professionalism, by the orientation of individual, groups, and class visit techniques. This is also carried out with the aim of improving the process of the learning activities, so all activities of the organization results in the efficient and effective learning. The effective and efficient learning can improve the student's learning outcomes and the quality of education.

This is in accordance with Kotirde \& Yunos' (2014) research entitled "The Processes of Supervision in Secondary Schools Educational System in Nigeria" describing the secondary school's supervisions in the country consisting of two stages namely the supervision of the principals and that of the teachers. Each stage focuses on supervising the output. The output of the firstly mentioned is on achieving the frequency and effectiveness of the rules, values, character, and gender competition in the school, while that of the later is on the exploration of the teacher's role, student's participation, motivation, and learning evaluation. 
Sidhu and Fook (2010) in their study entitled "Formative Supervision of Teaching and Learning: Issues and Concerns for the School Head" explain as supervisors, principals have to improve the quality of the teachers. This study highlights knowledge, understanding, and practice of elementary school principals as formative supervisors. The study also concluded that the principals had a limited understanding of the implementation of supervisions.

Another research conducted by Suryantini entitled "Improving the Supervision Competency of Principals through Group Supervision in Elementary Schools" concluded that: (1) the implementation of the managerial supervision was carried out through a cycle procedure consisting of three stages: preliminary meeting, observation, and follow-up meeting and (2) the supervision was effective to improve the principal's supervision competency. This is indicated by the results of the assessment that increased in each cycle of the actions.

Factors related to the implementation of learning supervision are: the process of program preparation, the approach used in the implementation of the supervision, and the follow-up activities. The stage of the supervision that has been implemented at vocational school SMK Pelita Bangsa Sumberlawang consisted of planning and implementation stages. To be exact, the follow-up stage has not yet been carried out by the teacher nor the school's principal. On this ground, the supervision became a formality for fulfilling the obligations.

The second descriptor of Hallinger and Murphy's leadership model is coordinating the curriculum. Curriculum is a guide used by teachers as a reference to develop the learning process. All learning activities, i.e. preparing the lesson plans, selecting the learning materials, determining the approaches and strategies/methods, selecting and determining the learning media, and determining the evaluation techniques, should all be oriented to it.

Curriculum must be arranged based on the demands of the changing era and the progress of the society. In other words, curriculum experience changes from time to time. Curriculum change is a necessity; if it does not experience adjustments and changes while the social life, technology, and other dimensions of life do, then it is a certainty that the curriculum is unable to meet the demands of change. As a result, everything taught in schools cannot keep up with the changes of the world of work.

The elaboration is in line with Adegbemile's study entitled "Principal's Competency Needs for Effective Schools Administration in Nigeria". As the title suggests, the focus of the study was the expected principals' administrative competencies to build the effective schools at secondary school level in South Geo West, Nigeria. It concludes the instructional leadership skill required by principals for effective school administration include that of the principals to: (1) collaborate with the teacher to determine the school's goals; (2) provide the facilities; (3) oversee the lesson plans; (4) monitor the teaching and learning activities; and (5) evaluate the plans and implementation of the curriculum.

The results of the study at elementary school SD Muhammadiyah Boyolali show that the curriculum applied were static and could not keep up with the changing era. As a result, there is a tendency for the graduates to be unable to keep the good work at the highly qualified schools of the higher level of education. 
The third descriptor is monitoring the student's learning progress. Monitoring is an activity performed by the principal in order to scrutinize the teacher's performance. In this case, the principal walked around the terrace of each classroom to ensure that the teachers carry out the teaching and learning activities as scheduled. Moreover, it is not uncommon for the principal to substitute for the teachers who had not yet present. The monitoring was carried out on the daily basis, so that the learning can be done effectively and efficiently.

The monitoring was also done by submitting the daily journals by the homeroom teacher once a week. Then, the class' daily journal was recapitulated as a report to the principal for the further actions. The submission was to determine the discipline of the teachers in carrying out the teaching, as well as the reports on the progress of the student's learning. By doing so, the principal knew what actions needed to be taken should anything regarding the learning problems occurred. Furthermore, the principal monitored the learning to ensure that the competencies in accordance with the process standards and the passing competences standard (SKL) were achieved.

\section{Promoting a Positive School-Learning Climate}

This dimension consists of six descriptors namely controlling the allocation of learning time, encouraging the professional development, focusing on achieving the vision, offering incentives for the teachers, setting the academic standards, and providing incentives for the students. Based on the study, the six aforementioned descriptors were able to promote a positive school-learning climate. The safe, comfortable, and pleasant (conducive) climate made the students more focused in the learning.

These findings are supported by the study conducted by Johnson, Uline, and Perez (2011), "Expert Noticing and Principals of High-Performing Urban Schools". This study aimed to examine the role of principal's instructional leadership in supporting the progress of schools located in the urban areas in the United States. The results show that the principals gave a high attention to the matters related to the student's involvement in the learning and the creation of the climate or atmosphere in the classroom. The principals were very concerned about how the teachers maintained the positive atmosphere for the learning.

In conclusion, in order to be able to implement an effective learning process, a positive school climate is fundamental. Setting the time for the students to do the learning, increasing the competence or professionalism of the teachers, and setting the academic standards of the teaching staff according to the laws and regulations can be a good starting point. Other things that can be done are focusing on achieving the vision of the school and giving appreciation in the form of incentives for teachers and students who excel. Should all the descriptors are able to run smoothly; the effective learning will be created. The fruit of an effective learning is the increasing student's learning outcomes.

\section{Conclusion}

To improve the quality of education, the principal implemented instructional leadership. The implementation was based on the model proposed by Hallinger and Murphy. Of the three dimensions used as the indicators of the leadership, only the dimension of framing the school's mission was not carried out by the principal on the grounds that the school's vision, mission, and goals were determined by the Foundation. The principal and staff were the 
executors who compile the school's programs oriented towards the goal's achievement. Moreover, learning management was carried out by supervising and evaluating the learning, coordinating the curriculum based on the demands of change and progress of the community, and monitoring the student's learning progress.

As it is mentioned earlier, principals must build a positive school climate. In this case, it was done by controlling the allocation of the learning time, encouraging the development of the teaching profession, focusing on achieving the school's vision, offering incentives for the excellent teachers, setting the academic standards in accordance with the laws and regulations concerning teachers, and providing incentives for the students with high achievement.

\section{Acknowledgeament}

We would like to thank various parties who have supported this research study. Our gratitude goes to the Directorate of Research and Community Service, the Directorate General of Research and Development of the Ministry of Research, Technology, and Higher Education for funding this multi-year research through the Postgraduate Research Grant. We are also sincerely grateful to the Director of the Graduate School and the Chair of the UMS Research Institute and its staff, who have provided the facilities and encouragement so we can conduct this study. We owe a debt of gratitude to the head of the Department of Education, the head and teachers of elementary school SD Muhammadiyah Boyolali, Central Java who helped us during the study so it went in accordance with the plan.

\section{References}

[1] Adegbemile, Oluwadare, 2011. Principal's Competency Needs for Effective Schools Administration in Nigeria,Journal of Education and Practice. www.iiste.org. ISSN: 2222-1735 (Paper) ISSN 2222-288X (Online) Vol 2 no 4 .

[2] Darno, 2013. Kepemimpinan Kepala Sekolah Dalam Meningkatkan Mutu Sekolah MI Tarbiyatul Athfal 03 Pengarasan Kecamatan Bantar Kawung Kabupaten Brebes Tahun Pelajaran 2011/2012. Thesis. Semarang: Graduate School, Semarang State University

[3] Erna Widiyanti. 2018. Pengaruh Kepemimpinan Kepala Sekolah dan Budaya Sekolah Melalui Motivasi Terhadap Kinerja Guru Sekolah Menengah Pertama Kota Semarang. Thesis. Semarang: Graduate School, Semarang State University

[4] https://en.wikipedia.org/wiki/Programme_for_International_Student_Assessment year 2015

[5] https://www.vedcmalang.com/pppptkboemlg/index.php/menuutama/departemen-bangunan-30/1352-bwijanarko, retrieved on Saturday, 8 June 2019 at 11.30

[6] Johnson, Joseph F., Jr., Cynthia L Uline, dan Lynne G.Perez. 2011. ”Expert Noticing and Principals of HighPerforming Urban Schools". Journal for The Education of Student Placed at Risk Vol 1, 2011. PP: 1-33, http://www.proquest.umi.com retrieved on 12 September 2018

[7] Decree of the Minister of National Education No. 162/U/2003 concerning Guidelines for Assigning Teachers as Principals

[8] Kotirde, I.Y \& Yunos J.B. Md, 2014. “The Processes of Supervision in Seconday Schools Educational System in Nigeria". Procedia Sosial and Behavioral Sciences, Vol.204.2015: pp 259-264

[9] Mulyasa. 2013. Menjadi Kepala Sekolah Profesional. Bandung. PT. remaja Rosdakarya

[10] Minister of Education and Culture Regulation No. 22/2016 concerning Basic and Secondary Education Process Standards

[11] Minister of National Education Regulation No. 13/2007 concerning School/Madrasah Principal Standards

[12] Priansa, Doni Juni, 2014, Manajemen Supervisi dan Kepemimpinan Kepala Sekolah, Bandung: Alfabeta 
[13] Prytula, Michelle, Brian Noonan, dan Laurie Hellsten. 2013. "Toward Instructional Leadership: Principals' Perceptions of Large Scale Assessment in Schools".Canadian journal of Educational Administration and Policy, Issue \#140, March 12, 2013, pp: 1-30, http://www.proquest.umi.com retrieved on 13 September 2018

[14] Sidhu, G Kaur dan Fook, Chan Yuen. 2010. "Formative Supervision of Teaching and Learning: Issues and Concerns for the School Head". European Journal of Scientific Research. Vol. 39 No. 4. Pg:589-605.

[15] Suryantini, 2016. Peningkatan Kompetensi Supervisi Kepala Sekolah Melalui Supervisi Kelompok di Sekolah Dasar, Jurnal Managemen Pendidikan. ISSN: 1907-4034, Vol 11, No. 2, Januari 2016: PP 9-17.

[16] Law No. 14/2005 concerning Teachers and Lecturers 